\title{
Estimated Right Ventricular Ejection Fraction
}

National Cancer Institute

\section{Source}

National Cancer Institute. Estimated Right Ventricular Ejection Fraction. NCI Thesaurus.

Code C135381.

A visual estimation of the volume of blood ejected from the right ventricle during ventricular systole. 